\section{Theory versus practice}

SIR-As a mere data-generator, I am no doubt ill-equipped to follow the deep theoretical meditations of Virginia A. Huszagh and Juan P. Infante ("The hypothetical way of progress"; Nature 338, 109; 1989), far less to criticize them. I am, apparently, caught up in a labyrinth of authoritarian ideology, stale paradigms and pseudo-hypotheses; nor is there anyone who could show me the way out of this maze, as all the creative minds have been driven off, and my fellow-prisoners are mediocre imitators who are unable even to make simple distinctions between speculation and theory. As a wretched product of such a dismal environment, shall I be forgiven for advancing the nonscientific and sociologically based view that this was one of the most inane pieces to be published in Nature in many months?

Department of Biochemistry and CHARLES JENNINGS

\section{Molecular Biology,}

Harvard University,

7 Divinity Avenue, Cambridge,

Massachusetts 02138, USA

SIR-Huszagh and Infante make several valid points in their plea for more encouragement for theoretical papers in biology. However, as the editor of a journal (BioSystems) which receives (and encourages) theoretical contributions, I take exception to the generalization that journals and reviewers tend to dismiss theoretical work out of hand. As Huszagh and Infante themselves acknowledge, there is much pseudo-theorizing, and the overall rejection rate in this area is probably justifiably high. More might be done to stimulate interactions between theoreticians and experimentalists by broadening our overspecialized science curricula, rather than by awarding grants.

ALAN W. SCHWARTZ

Laboratory for Exobiology,

Faculty of Science,

University of Nijmegen,

Toernooiveld 6525 ED,

Nijmegen, The Netherlands

SIR-It is with great interest and an immense sense of relief that we read the Commentary by Huszagh and Infante. The authors echo our own fears and experiences as $\mathrm{PhD}$ students. A PhD thesis seems meant solely to be a repository of unwieldly data - and data that conforms with the literature at that.

Things are not very different at seminars. Research data are presented and a particular explanation is offered where two or more possibilities might coexist and they are all dismissed on the grounds that "such examples are not found in the literature". Does the past trend of results govern the future course of science?
It is of course man's ability to think that changes the course of science, not the mere compilation and arrangement of data. Albert Einstein said: “. ... it appeared that it was possible to get certain knowledge of the objects of experience by means of pure thinking . . . Nevertheless, for anyone who experiences it for the first time, it is marvellous enough that man is capable at all to reach such degree of certainty and purity in pure thinking as the Greeks showed for the first time to be possible in geometry".

RADHA SRIRAM

KRISHNASWAMYS. KUMAR

Department of Biochemistry,

Osmania University,

Hyderabad, Andhra Pradesh,

India

\section{New kidneys}

SIR-The leading article (Nature 337, 393; 1989) about replacement kidneys reaches a conclusion with which few would disagree, namely that better international arrangements are need for collecting, matching and delivering kidneys to where people need them. In reaching this conclusion, the writer cites two reasons why a commerce in replacement organs should not be unthinkingly banned.

It would be imprudent to ban any practice unthinkingly, but if it is accepted (perhaps naively) that the role of the state is to ensure the well-being of its people, the first reason, as exemplified by the case of a parent who sells an organ in order to provide proper care for a handicapped child, becomes less compelling. An indigent parent is naturally willing enough to do all in his or her power to help a handicapped child, but society should not require that such a parent be exploited by the organ trade. The second reason given is that a law aiming to ban a commerce in replacement organs is unlikely to be effective. Similar objections were probably raised to laws against the slave trade. Admittedly, it is quite possible to draft an ineffective law, but much more frequently it is the enforcement of a law that is ineffective because enforcement depends to a large extent upon political will.

We are then left to consider the morality of a commerce in replacement organs. Commerce implies profit and an indigent who sells an organ is unlikely to profit from the sale. I do not know of any study of the longevity of organ donors, but it is possible that donation may adversely affect the life expectancy of a donor. If loss of life expectancy occurs during the earning period of a vendor's life, the profit from an organ sale that accrues in the long term to a seller is apt to be minimal.

There is reason to believe that a signifi- cant part of the profit from the sale of a replacement organ ends up not with the person who is the source of that organ but with the entrepreneur who arranges the deal. While the donation of an organ is an act greatly to be admired, reason requires that an exploitive commerce in replacement organs be speedily proscribed by internationally accepted and enforced legislation.

24 Prescott Place,

Pinawa, Manitoba,

Canada ROE 1 LO

\section{Apoptosis or apoptomeatic}

SIR-The use of the word 'apoptosis' to describe the active death of a cell is not new. The term is first attributable to a poet, Dioscoriades, who used it in the first century to describe the seasonal falling of flowers'. The Greek medical authors Hippocrates and Galen use the word to denote hair loss in balding gentlemen, or the weakening of bones with age. All these events could be caused by an active, programmed cellular response. Greater artistic licence was taken in the second century, with Esais, another Greek poet, using 'apoptosis' to refer to 'falling by the wayside' or 'backsliding' in a theological sense $^{2}$. This is presumably the origin of the definition located by Kleine ${ }^{3}$. Modern English dictionaries do not list the word, but contemporary medical ones do; they dissect it into 'apo' for 'head' and 'ptosis' 'to fall', with particular reference to balding. This may be an artificial division, but the exact origins of the term are unclear.

The 'apoptotic' $\mathrm{T}$ lymphocyte is something of a linguistic menagerie. 'Lympho' is derived from 'limpa', a Latin word for 'clear water', the ' $p$ ' being corrupted through Greek influence to 'ph' (just as the nypae became the nymphae). 'Cyte' on the other hand is a true Greek word meaning 'hollow vessel'. Clearly the process of activated cell death deserves accurate description: an alternative Greek word is 'apoptomeatic', this being an 'unlucky chance' or 'loss' as used by the authors Polybius ${ }^{4}$ and Athaneus'. However, as it is not mere fortune but instead a specific antibody that initiates cell death, as described by Smith et al. ${ }^{\circ}$, 'apoptosis' remains the more reasonable alternative. Perhaps 'apoptosis' should join the growing list of scientific terms for review in standard English dictionaries.

C. A. MICHIE

Queen Elizabeth Hospital for Children, London E2 8PS, UK

1. Dioscoriades Prooem 1, 8

2. Esais Parologia Graeca 34,4

3. Kleine, B. Nature 337, 402 (1989)

4. Polybius Historicus 11, 26.

5. Athaneus Mathematicus.

6. Smith, C. A. et al. Nature 337, 181-184 (1989). 